\title{
Application of the Doctrine of Binding Precedent in Malaysia: A Re- Evaluation
}

\author{
Nasrul Hisyam Nor Muhamad ${ }^{1,2}$, Mohd Khairy Kamarudin ${ }^{2}$, Abdul Basit Samat@Darawi², Sulaiman Shakib \\ Mohd Noor ${ }^{2}$, Ahmad Muhyuddin Hassan ${ }^{2} \&$ Aminuddin Ruskam² \\ ${ }^{1}$ Center of Research for Fiqh Science \& Technology (CFiRST), Faculty of Social Sciences and Humanities, \\ Universiti Teknologi Malaysia, Johor, Malaysia \\ ${ }^{2}$ Academy of Islamic Civilisation, Faculty of Social Sciences and Humanities, Universiti Teknologi Malaysia, \\ Johor, Malaysia \\ Correspondence: Nasrul Hisyam Nor Muhamad, Center of Research for Fiqh Science \& Technology (CFiRST), \\ Academy of Islamic Civilisation, Faculty of Social Sciences and Humanities, Universiti Teknologi Malaysia, Johor, \\ Malaysia. Tel: 60-7-555-7622. E-mail: nasrul@utm.my
}

Received: March 8, 2020

doi:10.5539/jpl.v13n3p263
Accepted: July 13, $2020 \quad$ Online Published: August 30, 2020

URL: https://doi.org/10.5539/jpl.v13n3p263

\begin{abstract}
This paper aims to analyze the issues concerning the implementation of binding precedent in Malaysian cases, and propose a re-evaluation of the binding precedent doctrine. The qualitative approach was employed to indicate the issues related to the doctrine of binding precedent by analyzing relevant cases. These cases were selected to propose the re-evaluation of the binding precedent doctrine as practiced by the Malaysian dual-judicial system. The main issue to be discussed regarding the doctrine of binding precedent is interference by the Civil Court on Islamic matters and Syariah Court decisions, which lead to inconsistency in judgments, even after the amendment of Article 121(1A) of the Federal Constitution. This study proposes that the application of binding precedent should be re-evaluated to ensure that the principles of justice are upheld. Court judges should decide cases based on merit, and only use previous judgments as guidance for present and future cases.
\end{abstract}

Keywords: Malaysian constitution, binding precedent, Malaysian legal system

\section{Introduction}

Common Law practices the doctrine of 'stare decisis' which it applies when the court is hearing a case, it must to refer to any previous case that has been decided as a precedent if the case has similar facts. In making the decision, the court is expected to indicate some legal principles in the previous case that are relevant to the current case. In turn. the decision must be consistent with the previous cases and it will strengthen the legal basis of the judgement (Owsia, 1991).

The doctrine of 'binding precedent' is derived from Common Law, and it means that a judge will adhere to the principles of law that were made or decided by previous judges on the subject to be a precedent (Guillaume, 2011). Stevens (2018) explains that precedents are former cases that assist judges through binding, authoritative decisions to resolve their present case. Binding precedent is necessary to clarify organizational decisions in recurrent situations (Gehring, Dorsch, \& Dörfler, 2019). Murgan et al., (2015) underlined the advantages of binding precedent which could avoid waste of judicial effort and time to rethink solutions to similar previous problems and encourage uniformity in judgments. Binding precedent is to guarantee the coherence and predictability of judicial decisions and to provide stable social relations (Alvim, 2018). At the same time, precedents manage jurists and standardize their different principles in interpreting the law. Thus, it prevents inferior courts from disregarding the precedents set by the superior courts (Re, 2016).

The court must resolve what weight to give to its own previous judgment with respect to specific agencies. Once the court has acknowledged that a definite legal passage has specific connotation, it is very unusual for the court to later change its cognizance (Edmundson, 2018). Larsson, Naurin, Derlén, \& Lindholm, (2017) indicated that legal factors and more complex cases could increase the use of precedent. Meanwhile, Derlén \& Lindholm (2015) discovered that the precedential power of a judgment is positively correlated to the number of cases. 


\section{Malaysian Legislation: An Overview}

In Malaysia, generally Article 121-131 of Federal Constitution empowers Civil Courts to administer Civil Law of the country. While, Syariah Courts of States and Federal Territories that are to govern matters relating to Islamic law as have been established under Ninth Schedule, State List (item1) and Federal List item (6)(e) of Federal Constitution. At the Federal Court level which the highest court in Malaysia, is bound to the previous decision in a case with similar fact. The decision of the Federal Court also binds the lower court such as the Court of Appeal, High Court and Magistrate Court. In this case, if the lower courts do not adhere to this binding precedent doctrine, then the judge would have neglected his/her duty. At the same time, the courts need to adhere proper procedures and laws in conducting a jugdment (Chik, 2009; Mohamed, 2014).

Unlike Civil Courts, Shariah Courts in their judicial matters are more independent. Obviously, the doctrine of binding precedent is not applicable in Malaysian Syariah Courts. The judgment in Islamic judicial system is dependent on the 'ijtihad' (intellectual reasoning) of the Judge based on two main sources. 'Al-Quran' and 'AsSunah'. In addition to the primary sources, the Judges may also apply other secondary sources of references such as 'qiyas' (analogical reasoning), 'istihsan' (juristic discretion), 'maslahah mursalah' (consideration of public interest) and 'sadd zarai" (blocing the means). The emphasis on Islamic sources of references is the primary identity of Syariah Court that distinguhishes to the Civil Court. Additionally to the sources of references, Syariah Courts stressed on the facts of the cases, oral evidences, documents and 'qarinah' (circumstantial evidence) (Bahnisi, 1989; Tapah, 2008; Zaydan, 2006).

Wan Muhammad \& Abdul Salam (2018) recommend that the Malaysian Syariah Court should loosen the judgment of punishment from the binding precedent doctrine which is occasioned to a fairly similar nature of punishment. It is significant to restore the uprightness of the offender and the harmony of the people. In addition, Syariah Law has a wide definition as a general understanding or restriction, direction or regulation (Shuaib, 2019). The doctrine of binding precedent means that decisions of the superior courts are binding upon the inferior courts in subsequent similar cases. This doctrine has been practiced till now without any conflict (Dahlan \& Palil, 2018; Subramaniam \& Nicholas, 2018). However, in a dual-judicial system (Civil Law and Syariah Law), there is an issue of jurisdiction involving Islamic matters as the Syariah Court does not practice binding precedent in their cases, even though several attempts have been made to promote binding precedent in the Syariah court (Azalan \& Mohamed Said, 2016; Mahmod \& Buang, 2016; Murgan, Ghafur, \& Ansari, 2015). Thus, this paper analyzes the issues of binding precedent and how a re-evaluation of the binding precedent doctrine could overcome this problem.

\section{Method}

This paper applied the document analysis to evaluate the binding precedent doctrine to overcome issues in the context of judgments involving Islamic matters. Data was collected through relevant cases that are in line with the binding precedent doctrine. Document analysis was employed to analyze the issue of application of the doctrine and how the re-evaluation can be done.

\section{Issues of Implementation of the Doctrine of Judicial Precedent in Malaysia}

The application of English Law started from the arrival of the British to the Malay region 150 years ago through the First Charter of Justice, which contributed to a profound impact on the Malaysian legal system (Sulong, 2013). The binding precedent doctrine has been applied in Civil Courts, and even in Islamic matters. This can be seen in the Federal Court case of Tengku Mariam v Commissioner for Religious Affairs, Terengganu. The court applied the binding precedent doctrine and set aside the Mufti's (Muslim scholar) decision, where the Mufti had issued a fatwa regarding the validation of waqf (Islamic endowment). In that case, the decision was made by the Privy Council, in which the cases of Abdul Fata Mohamed Ishak v Rasamaya Dhur Chowdhury [1894] L.R 221A 76 and Fatimah binti Mohamad v Salim Bahshuwen [1952] A.C.1 were followed and recognized as binding on the Court, even though the decision did not meet Islamic requirements (Muneeza, 2017). Conflict will remain because the application of the binding precedent doctrine by the Civil Court does not recognize Syariah Court judgments, which is contrary to Civil Court precedent as referred to in Ainan v Syed Abu Bakar [1939] MLJ 209, Myriam v Mohamed Ariff [1971] 1 MLJ 275, Commissioner for Religious Affairs, Terengganu \& Ors. v Tengku Mariam [1969] 1 MLJ 110, and Nafsiah v Abd. Majid [1969] 2 MLJ 174 (Che Pa, Nor Muhammad, \& Mustar, 2016).

The amendment of Article 121(1A) of the Federal Constitution in 1988 gave exclusive jurisdiction to the Syariah Court to deal with matters relating to Islam. However, there have been several occasions where the Civil Court interfered with the Syariah Court's decisions. This is evidenced in the case of Indira Ghandi A/P Mutho v Director of the Islamic Religious Department of Perak \& Ors [2013] 5 MLJ 552, which showed that the Civil Court is still adamant in using the binding precedent doctrine to revise the decisions of the Syariah Court. In the Indira Ghandi case, there is conflict with the case of Soon Singh v Pertubuhan Kebajikan Islam Malaysia (PERKIM) [1999] 1 
MLJ 489, which ruled that only the Syariah Court could handle cases related to Islam. Thus, the Civil Court should respect the position of the Syariah Court by not interfering in matters under the Syariah Court's jurisdiction, which was the approach taken by the Court of Appeal and the Federal Court in the cases of Selangor Islamic Religious Council v Bong Boon, Chuen \& Ors [2008] 6 MLJ 488, Soon Singh v Pertubuhan Kebajikan Islam Malaysia (PERKIM) [1999] 1 MLJ 489 and Sulaiman bin Takrib v Terengganu Government (Government of Malaysia, Intervener) [2009] MLJ 354 (Kusrin, Hamjah, \& Md Sham, 2015; Mohd Salim, 2016; Shuaib, Kamal, Bustami, Othman, \& Sulaiman, 2017).

The Federal Court case of Latifah bte Mat Zin v Rosmawati binti Sharibun [2007] 5 MLJ 10, was especially unsatisfactory, when the Civil Court yet again delivered a different judgment from the Syariah Court (Kamarudin, Zaman, \& Meor Razak, 2019; Nor Muhamad et al., 2019). Similarly, in the case of Indira Gandhi a/p Mutho v Patmanathan a/l Krishnan [2015] 7 MLJ 153, Judge Lee Swee Seng decided a case involving the custody of a Muslim child, which was given to the child's non-Muslim mother. Yet another example is the case of Muhamad Juzaili Mohd Khamis \& Ors v State Government of Negeri Sembilan \& Ors [2015] 1 SHR 6, where an appeal was made on the judgment of the High Court that acknowledged transgenders because it is a fundamental right as guaranteed by the Federal Constitution (Che Pa et al., 2016; Shuaib, 2019). Clearly, the Civil Court appropriated the general approach as in the case of Tunku Abdul Rahman ibni Almarhum Sultan Abdul Hamid [1998] 4 MLJ 623 , in which the Judge held that the Civil Court had jurisdiction over matters not included within the jurisdiction of the Syariah Court, which is limited specifically to matters concerning Islam. It was argued that unless the State Legislature does not enact any relevant laws that allows the Syariah Court to hear cases other than stipulated in the State List of the Federal Constitution, there is no obstruction to the Civil Court to exercise its jurisdiction. This decision does not however take into account the case of Ramah v Laton [1927] FMSLR (CA), which recognized Islamic law as a whole, and not just what is enacted (Abdul Rashid, 2013; Mohd Nor, Abdullah, \& Ali, 2016; Wan Adnan \& Buang, 2019). Based on these cases, a re-evaluation of the application of binding precedent should be undertaken to ensure and realize the harmonization of court jurisdiction and justice of the judgments.

\section{Re-Evaluation of Binding Precedent}

Criticism has been made against the binding precedent doctrine due to its violation of the principle of justice in judgments of some cases. Past and present decisions made based on the doctrine of binding precedent doctrine often differ in terms of analysis from one case to another, even though they essentially involve similar facts and statutes or laws. It is quite possible for inferior courts to propose inaccurate justifications to align binding precedent based on the facts of the case and the law to which it is intended (Bruhl, 2014). The inferior courts have no power to propose new decisions that are different from previous decisions by the High Court. One such case of a judgment made per incuriam is that of United States v City of Philadelphia, 482 F. Supp. 1248, in which the Supreme Court set a precedent for going against previous decisions (Franklin, 1981).

Although the Syariah Court is not bound by preceding decisions, earlier judgments are referred to if they involve similar laws and facts, and they do not conflict with Islamic law as stipulated in 'Practice Instruction, no. 1, 2002' by the Department of Syariah Judiciary Malaysia. This position is not the same as the practice in the Civil Court which is 'compelled' to bind the precedent even on per incuriam. This approach shows that the Syariah Courts in Malaysia have lead the Civil Court from using strict precedent in their judgment (R. Dahlan \& Faudzi, 2015).

Revision must also be made to Item 1 of the States List in the Federal Constitution on the Syariah Court's Criminal Jurisdiction. This revision is necessary because Syariah Court jurisdiction is limited, and many matters relating to Islamic law are excluded from jurisdiction by Federal Law and the Syariah Court Act (Criminal Jurisdiction) 1965. Although exclusive power is given, there are various constitutional and parliamentary restrictions that prevent Islamic law or the authority of Syariah Court to operate without obstruction.

The application of binding precedent which involves per incuriam needs to be reviewed to ensure the principles of justice. For instance, the judgment of the Federal Court in the case of Government of Malaysia v Lim Kit Siang [1988] 2 MLJ 12 was significant in terms of access to the court in relation to the decisions, actions and omission of the public authorities for judicial review. This review would not have been possible for all the precedents made since through the case Yeap Cheah Neo v Ong Cheng Neo [1975] 6 LR 381, but it would have been sufficient to be the benchmark, especially post-Independence. In cases involving the Privy Council, a review of the doctrine of binding precedent should be made on a case-by-case basis due to the gradual abolition of appeals to the Privy Council up to 1985 (Clarry, 2014).

\section{Conclusion}

The binding precedent doctrine plays a prominent role in the Common Law system but not in the Islamic judicial system. In Islam, each case is decided on its own merit, and former judgment will only be considered as a guide 
for present and future cases. Therefore, in countries which practice dual-judicial systems as in Malaysia, a reevaluation of the doctrine of binding precedent is necessary, and can be an effective mechanism for recognizing the practices of different judicial systems. It can also become a mechanism for furthering the judiciary as an institution of justice.

\section{Acknowledgments}

Special thanks to Ministry of Higher Education (MOHE) of Malaysia, Fundamental Research Grant Scheme (FRGS); Universiti Teknologi Malaysia - no. grants: FRGS/1/2014/SSI03/UTM/02/2 \& FRGS/1/2014/SSI03/UTM/02/7 to support this research.

\section{References}

Abdul Rashid, R. (2013). Memartabatkan undang-undang Islam dan Mahkamah Syariah dalam undang-undang tanah di Malaysia. Jurnal Hadhari, 5(2), 27-36.

Alvim, E. A. (2018). Information on legal precedent as an instrument to ensure legal certainty for citizens. International Journal of Open Government, 7, 243-254.

Azalan, N. S., \& Mohamed Said, N. L. (2016). Keputusan Hakim Syarie Dalam Kes-Kes Pengesahan Hibah Mengenai Sighah. Journal of Contemporary Islamic Law, 1(1).

Bahnisi, A. F. (1989). Nazariyat al-Istibat fi al-Fiqh al-Jinai al-Islami. Cairo: Dar al-Shuruq.

Che Pa, H., Nor Muhammad, N. H., \& Mustar, S. (2016). Bidang kuasa eksklusif Mahkamah Syariah selepas pindaan Perkara 121(1A) Perlembagaan Persekutuan: Satu penilaian. Malaysian Journal of Syariah and Law, 3,1-13. Retrieved from http://mjsl.usim.edu.my/index.php/jurnalmjsl/article/view/12

Chik, F. T. (2009). Penulisan teks penghakiman di Mahkamah Sivil: Kaedah dan pendekatan. Jurnal Hukum, 28(2), 33-43.

Dahlan, N. K., \& Palil, M. R. (2018). Alternative Dispute Resolution for Islamic Finance in Malaysia. Jurnal Undang-Undang \& Masyarakat, 22, 11-29. https://doi.org/10.1051/matecconf/201815005077

Derlén, M., \& Lindholm, J. (2015). Characteristivs of precedent: The Case law of the European Court of Justice in three dimensions. German Law Journal, 16(5), 1073-1098. https://doi.org/10.1017/s2071832200021040

Edmundson, W. A. (2018). Precedent and United States Administrative Law. Studia Iuridica Lublinensia, 27(1), 69-74. https://doi.org/10.17951/sil.2018.27.1.694

Gehring, T., Dorsch, C., \& Dörfler, T. (2019). Precedent and doctrine in organisational decision-making: The power of informal institutional rules in the United Nations Security Council's activities on terrorism. Journal of International Relations and Development, 22(1), 107-135. https://doi.org/10.1057/s41268-017-0101-5

Guillaume, G. (2011). The use of precedent by international judges and arbitrators. Journal of International Dispute Settlement, 2(1), 5-23. https://doi.org/10.1093/jnlids/idq025

Kamarudin, M. K., Zaman, N., \& Meor Razak, R. (2019). Thematic analysis on the necessity of hibah law in Malaysia. Al-Qanatir International Journal of Islamic Studies, 16(1), 1-13.

Kusrin, Z. M., Hamjah, S. H., \& Md Sham, F. (2015). Muslim father's rights in determining his minor child's conversion to Islam in Malaysia. European Journal of Social Sciences Education and Research, 4(1), 15. https://doi.org/10.26417/ejser.v4i1.p15-21

Larsson, O., Naurin, D., Derlén, M., \& Lindholm, J. (2017). Speaking Law to Power: The Strategic Use of Precedent of the Court of Justice of the European Union. Comparative Political Studies, 50(7), 879-907. https://doi.org/10.1177/0010414016639709

Mahmod, Z., \& Buang, A. H. (2016). Judiciary and judicial decision of the Shariah Courts in Malaysia: A literature review. Journal of Shariah Law Research, 1(2), 201-212.

Mohamed, A. A. A. (2014). Malaysian legal system. Selangor: The Malaysian Current Law Journal Sdn Bhd.

Mohd Nor, M. R., Abdullah, A. T., \& Ali, A. K. (2016). From Undang-undang Melaka to federal constitution: The dynamics of multicultural Malaysia. SpringerPlus, 5(1), 1683. https://doi.org/10.1186/s40064-016-3360-5

Mohd Salim, W. N. (2016). The effect of apostasy on the entitlement to property upon death: The Malaysian position. IIUM Law Journal, 24(2), 359-375. Retrieved from http://journals.iium.edu.my/iiumlj/index.php/iiumlj/article/viewFile/269/200

Muneeza, A. (2017). Application of law of evidence to Islamic banking with special reference to Malaysia. 
International Journal of Islamic and Middle Eastern Finance and Management, 10(4), 503-518. https://doi.org/10.1108/IMEFM-02-2016-0025

Murgan, M. G., Ghafur, A., \& Ansari, A. H. (2015). Operation of judicial precedent in Malaysia and Nigeria: A comparative analysis. International Journal of Law, 1(1), 29-35. Retrieved from www.lawresearchjournal.com

Nor Muhamad, N. H., Kamarudin, M. K., Abdullah, A. H., Sholehuddin, N., Abdul Hamid, M. F., Muhidin, I., \& Abdul Karim, K. (2019). Islamic inter vivos law challenges in Malaysia. Journal of Legal, Ethical and Regulatory Issues, 22(1), 1-6.

Owsia, P. (1991). Sources of Law under English, French, Islamic and Iranian Law: A comparative review of legal techniques. Arab Law Quarterly, 6(1), 33-67. https://doi.org/10.2307/3381891

Re, R. M. (2016). Narrowing Supreme Court precedent from below. The Georgetown Law Journal, 104(921), 921971.

Shuaib, F. S. (2019). Administration of Islamic Law and Human Rights: The basis and its trajectory in Malaysia. Al-Jami'ah: Journal of Islamic Studies, 56(2), 281-304. https://doi.org/10.14421/ajis.2018.562.281-304

Shuaib, F. S., Kamal, M., Bustami, T., Othman, N., \& Sulaiman, M. (2017). Towards an apex Sharia court in Malaysia. Pertanika Journal of Social Sciences and Humanities, 25(Special Issue), 309-322.

Stevens, K. (2018). Reasoning by precedent - between rules and analogies. Legal Theory, 24(3), $216-254$. https://doi.org/10.1017/S1352325218000113

Subramaniam, Y., \& Nicholas, C. (2018). The courts and the restitution of indigenous territories in Malaysia. Erasmus Law Review, 11(1), 67-79. https://doi.org/10.5553/elr.000096

Sulong, D. J. (2013). The Influence of English Law for the Local: A Study on the Administration of. Journal of US-China Public Administration, 10(4), 422-431. https://doi.org/10.1108/EUM0000000001727

Tapah, S. (2008). Penulisan teks penghakiman kes-kes mal di Mahkamah Syariah. In R. Md Noor (Ed.), Penulisan Teks Penghakiman di Mahkamah Syariah (pp. 45-51). Kuala Lumpur: Penerbit Universiti Malaysia.

Wan Adnan, W. A., \& Buang, A. H. (2019). Pelaksanaan sulh dalam kes melibatkan tuntutan hartanah orang-orang Islam di Mahkamah Syariah di Malaysia: Tinjauan kajian lepas. Journal of Shariah Law Research, 4(1), 2754.

Wan Muhammad, R., \& Abdul Salam, K. (2018). The concept of retributive and restorative justice in Islamic criminal law with reference to the Malaysian Syariah court. Journal of Law and Judicial System, 1(4), 8-16. Retrieved from http://irep.iium.edu.my/66776/

Zaydan, A. K. (2006). Nizam al-Qada'fi al-Shari'ah al-Islamiyyah. Beirut: Muassasah al-Risalah.

\section{Copyrights}

Copyright for this article is retained by the author(s), with first publication rights granted to the journal.

This is an open-access article distributed under the terms and conditions of the Creative Commons Attribution license (http://creativecommons.org/licenses/by/4.0/). 